\title{
Response of Growth and Productivity of Cowpea Plants to Nano Mixture of Micronutrients Under Different Potassium Sulphate Fertilizer Rates
}

\author{
Zyada H. G. ${ }^{1}$, Sabreen Kh. A. Ibraheim ${ }^{1}$, F. M. El-Saadony ${ }^{2}$, Mohamed I. Mohaseb ${ }^{3 *}$ \\ ${ }^{1}$ Horticulture Department, Faculty of Agriculture, Zagazig University, Egypt \\ ${ }^{2}$ Agriculture Botany Depatrmrnt, Faculty of Agriculture, Zagazig University, Egypt \\ ${ }^{3}$ Soil, Water and Environment Research Institute, Agriculture Research Center, Giza, Egypt \\ Email: mohasebmohamed@yahoo.com
}

Received: 15 June 2020; Revised: 10 August 2020; Accepted: 10 August 2020

\begin{abstract}
The response of cowpea cv. Cream 7 growth and productivity to potassium fertilization mixed with or without Nano mixture of micronutrients were studied during the summer of 2017 and 2018 seasons at Experimental Farm, Faculty of Agriculture, Zagazig University, Egypt. The experiment aimed to assessed the effect of potassium fertilization levels $\left(0.0,24,48\right.$ and $\left.72 \mathrm{~kg} \mathrm{~K}_{2} \mathrm{O} / \mathrm{Fed}\right)$, Nano mixture of micronutrients rate $(0.0,0.50,1.0$ and $2.0 \mathrm{~g} / \mathrm{l})$ and their interactions on growth, seed yield, macronutrients concentration in shoot and seeds and seed quality of cowpea plants. Source of potassium levels was potassium sulphate $\left(48-52 \% \mathrm{~K}_{2} \mathrm{O}\right)$. The used Nano mixture of micronutrients called "Magrow NanoMix" and it contained Fe (6\%), Zn (6\%), B (2\%), Mn (5\%), Cu (1\%) and Mo (0.1\%). These treatments arranged in a split-plot design with three replicates. The results referred to that fertilizing cowpea plants with potassium at $72 \mathrm{~kg} \mathrm{~K}_{2} \mathrm{O} / \mathrm{Fed}$. significantly increased cowpea growth (plant height, branch and leaf numbers per plant as well as branch, leaf and total dry weights/plant), yield components (pod diameter and length, hundred seeds weight, pod number/plant and seed yield/plant and/Fed.) as well as chemical constituents (N, P and K percentages in each leaves and seeds as well as total carbohydrates and protein percentages in seeds, also, total chlorophyll content (SPAD) in cowpea leaves compared with control and the lowest levels under study. The same trend was achieved by using the highest rate of Nano mixture of micronutrients $(2 \mathrm{~g} / \mathrm{l})$ regarding the increase in most of abovementioned parameters of growth, yield and chemical constituents of cowpea compared with unsprayed plants (control). In general, application of potassium fertilization at $72 \mathrm{~kg} \mathrm{~K}_{2} \mathrm{O} / \mathrm{Fed}$. as soil application with Nano-mixture of micronutrients at $2 \mathrm{~g} / \mathrm{l}$ rate as foliar spray was recorded the best treatments for increasing all cowpea growth and seed yield components as well as $\mathrm{N}, \mathrm{P}, \mathrm{K}$ and carbohydrates percentage in seeds such as compared with control treatment (without using mineral potassium or Nano mixture of micronutrients) in growing season.
\end{abstract}

Keywords: cowpea, potassium fertilization, nano mixture of micronutrients, growth, seed yield, chlorophyll and NPK percentages

\section{Introduction}

Cowpea [1] is a vegetable summer plant belonging to the legume family. It is considered as one of the major

Copyright (C2020 Mohamed I. Mohaseb, et al.

DOI: https://doi.org/10.37256/jba.112021485

This is an open-access article distributed under a CC BY license

(Creative Commons Attribution 4.0 International License)

https://creativecommons.org/licenses/by/4.0/ 
vegetable crops grown in Egypt for local consumption and exportation. Cowpea seeds contain high content of protein and rich in several amino acids [2]. Also, cowpea plants are at most utilized for human consumption, green manure, soil cover and livestock feed [3].

Potassium is one of the seventeen essential elements required for plant development and growth, and one of the 3 most important nutrients (, $\mathrm{P}$ and $\mathrm{K}$ ). $\mathrm{K}$ could be a soil commutable ion and is actively taken in by plant roots. Potassium (K) in enzyme activation, plays a say to assist substrate engaged by lowering energy partitions in the transition states or rather than being the operator of giving rise in catalysis [4]. It a critical element of the numerous soil and is in the end derived from the weathering of soil principle materials like K-aluminum-silicates in the soil. Potassium although a nearness of the ion interchange complex, is simply weak driving to the soil particles and is very leachable. If plants and stand by organisms holding potassium as set free ions in their cells once associate degree organism dies, its mineral reenters the soil reply [5]. The yield parameters progressively increased as rates of K increased. Highest number of fresh pods/plant and seeds/pod, heaviest fresh pods per plant and hectare as well as seed yield of cowpea were associated with $45 \mathrm{~kg} / \mathrm{ha} \mathrm{K}_{2} \mathrm{O}$ application [1]. Between potassium sulphate levels, the maximum level (140 kg/ha) significantly higher in grain yields for $18.39 \%$ and improve growth of cow pea [6].

In between, nanotechnology make out its place in agricultural sciences and regarding industries, as an interdisciplinary technology and a major in dissolving problems and scarceness. Nanotechnology has many implementations in all stages of production, storing, packaging and transport of agricultural products. The employ of nanotechnology in agriculture and forestry will have ecological advantages [7]. Nanotechnology has also shown its capability in adjusting the development of the plant growth thereby helping in further improvement of crop yields [8]. Micronutrients like iron, zinc, copper and manganese have become yield-limiting factors and are partly responsible for poor food nutritional quality. Micronutrient Nano mixture of micronutrients fertilizers may enhance the availability of these micronutrients in plants and increase crop productivity [9]. Moreover, fennel plants treated with Nano mixture of micronutrients mixture (Magrow Nano Mix) showed an increase in vegetative growth, yield, volatile oil production and chemical constituents when compared with un-treated plants [10].

The purpose of this work was the response of cowpea (Cream-7 cultivar) growth, seed yield and chemical constituents to different levels of potassium fertilization and rates of Nano mixture of micronutrients mixture as well as their interactions. Besides, trying to reach the maximum cowpea productivity per unit using different potassium fertilization levels combined with Nano mixture of micronutrients rates.

\section{Materials and methods}

This work was done at Experimental Farm, Fac. Agric., Zagazig University, Egypt during the two consecutive summer seasons of 2017 and 2018, to study the effect of potassium fertilization levels as soil drench and Nano mixture of micronutrients rates as foliar application and their interaction treatments on cowpea growth and seed yield components as well as chemical constituents in leaves and seeds of cowpea plants under Sharkia Governorate conditions. This experiment included 16 treatments which were the combination between four K-fertilization levels $\left(0.0,24,48\right.$ and $72 \mathrm{~kg} \mathrm{~K}_{2} \mathrm{O} / \mathrm{Fed}$.) and Nano mixture of micronutrients rates $(0.0,0.50,1.0$ and $2.0 \mathrm{~g} / \mathrm{l})$. These treatments arranged in a split-plot design with three replicates. The main plots are assigned to potassium fertilization levels and the sub plots deviated to Nano mixture of micronutrients rates. The physical and chemical properties of the experimental soil site (average of the two seasons) according to Chapman and Pratt ${ }^{[11]}$ are shown in Table 1.

Table 1. Physical and chemical properties of experimental soil (average of the two seasons)

\begin{tabular}{|c|c|c|c|c|c|c|c|c|c|c|c|}
\hline \multicolumn{9}{|c|}{ Physical analysis } & \multicolumn{3}{|c|}{ Soil texture } \\
\hline & \multirow{2}{*}{$\begin{array}{c}\text { Clay }(\%) \\
56.36\end{array}$} & \multirow{3}{*}{$\begin{array}{c}\text { Silt (\%) } \\
9.26\end{array}$} & \multicolumn{3}{|c|}{ Fine sand $(\%)$} & \multicolumn{3}{|c|}{ Coarse sand $(\%)$} & \multirow{2}{*}{\multicolumn{3}{|c|}{ Clay }} \\
\hline & & & \multicolumn{3}{|c|}{17.62} & \multicolumn{3}{|c|}{16.76} & & & \\
\hline \multicolumn{11}{|c|}{ Chemical analysis } & \\
\hline \multirow{2}{*}{$\mathrm{pH}$} & \multirow{2}{*}{$\begin{array}{l}\text { E.C. } \\
\mathrm{dS} / \mathrm{m}\end{array}$} & \multirow{2}{*}{$\begin{array}{c}\text { Organic matter } \\
(\%)\end{array}$} & \multicolumn{3}{|c|}{ Soluble cations (meq./L) } & \multicolumn{3}{|c|}{ Soluble anions (meq./L) } & \multicolumn{3}{|c|}{ Available $(\mathrm{mg} / \mathrm{kg})$} \\
\hline & & & $\mathrm{Mg}^{++}$ & $\mathrm{Ca}^{++}$ & $\mathrm{Na}^{+} \mathrm{K}^{+}$ & $\mathrm{Cl}^{-}$ & $\mathrm{HCO}_{3}^{-}$ & $\mathrm{SO}_{4}^{--}$ & $\mathrm{N}$ & $\mathrm{P}$ & K \\
\hline 7.84 & 0.98 & 0.61 & 1.7 & 2.5 & 4.80 .8 & 7.5 & 0.5 & 1.8 & 55 & 7 & 120 \\
\hline
\end{tabular}


The experimental unit area was $9 \mathrm{~m}^{2}$ (five ridges with $3 \mathrm{~m}$ lengths for each and $60 \mathrm{~cm}$ widths). Two ridges are utilized for determining growth characters and the others three ridges were utilized for determining cowpea seed yield and chemical determination. The Cream-7 cultivar of cowpea plant was produced by Hort. Res. Inst., Agric. Res. Center, Egypt. Cowpea seeds were sown on $22^{\text {th }}$ and $27^{\text {th }}$ June during the 2017 and 2018 seasons, respectively in hills (2-3 seeds/hill) at $20 \mathrm{~cm}$ apart and then thinned after fully emergency to leave $1 \mathrm{plant} / \mathrm{hill}$.

Cowpea plants were fertilized with potassium (as potassium sulphate $48-52 \% \mathrm{~K}_{2} \mathrm{O}$ ) at different levels three times at 25, 40 and 55 days after seed sowing. Nano mixture of micronutrients (Magrow Nano Mix) was obtained from Modern Agricide Company (New Cairo, Cairo, Egypt)as a powder, micro-nutrients Nano crystallite powder was synthesized by high-energy ball milling. Powder mixture is conducted in a 0.4 mini lab planetary ball mill (model BECO-PBM-V-0.4 L, Changsha Deco Equipment Co., Ltd., China) to 40 hours using ball to powder mass ratio of 8:1 by prof. Dr. Osama M. Hemeda at Central lab., Physics Department, Faculty of Science, Tanta University, Egypt. The microstructure of the sintered samples examined using High Resolution Transmission Electron Microscope (HRTEM) model JOEL EM 2-100. The size of micro-nutrients Nano-particles, as evident from the TEM images found to be $50 \mathrm{~nm}$. It contained six essential substances of plant nutrition; i.e., $\mathrm{Fe}(6 \%), \mathrm{Zn}(6 \%), \mathrm{B}(2 \%), \mathrm{Mn}(5 \%), \mathrm{Cu}(1 \%)$ and $\mathrm{Mo}(0.1 \%)$ at rates $(0.5,1.0$ and $2.0 \mathrm{~g} / \mathrm{L})$ as well as citric acid $(4 \%)$ to reduce $\mathrm{pH}$ of spray solution to enhance absorption. Nano mixture of micronutrients was applied as foliar application at 25,35 and 50 days after seed sowing. The untreated plants were sprayed with tap water (as control).

All experimental plots received similar amounts of calcium superphosphate $\left(15.5 \% \mathrm{P}_{2} \mathrm{O}_{5}\right)$ at $150 \mathrm{~kg} / \mathrm{Fed}$., and ammonium sulphate $(20.5 \% \mathrm{~N})$ at $45 \mathrm{~kg} / \mathrm{Fed}$. All amounts of phosphorus fertilizer and one third of potassium sulphate were added during soil preparation, while the other two third of potassium sulphate and nitrogen fertilization were added in two equal rates at 30 and 50 days after sowing. The other agricultural practices such as pest, weed and disease dominance on all units were executed according to the commendations of Agriculture Ministry, Egypt.

\subsection{Data recorded}

\subsubsection{Plant growth parameters}

Three plants from each experimental unit were randomly taken for 60 days after sowing and plant height $(\mathrm{cm})$, and number of leaves/plant and number of branches/plant were recorded. Different plant parts; i.e., branches and leaves were oven dried at $70^{\circ} \mathrm{C}$ still constant weight, then their dry weight of branches/plant (g), dry weight of leaves/plant (g) and total dry weight of the plant $(\mathrm{g})$ were recorded.

\subsubsection{Yield components}

At maturity stage, dry pods of each from each plot were harvested and number of pods/plant average seed yield/ plant $(\mathrm{g})$ were recorded, then, total yield/Fed were calculated. 30 dry pods from each plot were randomly taken to determine pod dimensions (diameter and length), hundred seed weight where, the Fed area is $4200 \mathrm{~m}^{2}(0.42 \mathrm{ha})$ and it was cultivated with about 3500 cowpea plants.

\subsubsection{Potassium use efficiency (KUE)}

It was calculated according to the equation of Janssen [13] as follow:

(seed yield $\mathrm{kg} / \mathrm{kg} \mathrm{K} \mathrm{K}_{2} \mathrm{O}$ )

Where, $\mathrm{Yk}$ is yield as the particular $\mathrm{K}$ level, $\mathrm{Y} 0$ is yield at $\mathrm{K} 0$ level (control) and $\mathrm{Kr}$ is particular $\mathrm{K}$ rate

\subsubsection{Chemical constituents in leaves and seed quality}

Nitrogen, phosphorus and potassium percentages were determined in leaves at 60 days after sowing according to the methods described by Chapman and Pratt [11]. Also, total chlorophyll content (SPAD unit) was determined in cowpea leaves after 60 days from sowing date by using SPAD-502 meter [12]. Nitrogen, phosphorus and potassium percentages were determined in dry seeds according to the methods described by Chapman and Pratt [11]. Besides, protein percentage (nitrogen percentage $\times 6.25$ ) and total carbohydrates percentage after harvesting in two consecutive seasons. 


\subsection{Statistical analysis}

Collected data were analyzed according to Gomez and Gomez [14]. Least significant difference (L.S.D.) was utilized to differentiate means at the at $5 \%$ level of probability. The means were compared using computer program of Statistics version 9 [15].

\section{Results and discussion}

\subsection{Plant growth}

Data of both seasons in Tables 2 and 3show that, growth characters of cowpea grown in clay soil increased with increasing $\mathrm{K}_{2} \mathrm{O}$ rates up to $72 \mathrm{~kg} / \mathrm{Fed}$. After 60 days from sowing in both seasons. The highest values in cowpea plant height, branch and leaf numbers and dry weights as well as total plant dry weight were achieved by $72 \mathrm{~kg} \mathrm{~K}_{2} \mathrm{O} /$ fed. Compared with control and the other rates under studying in both seasons, increases in total dry weight/plant were about 34.21 and $29.46 \%$ for $\mathrm{K}_{2} \mathrm{O}$ at $72 \mathrm{~kg} /$ Fed., 24.28 and $13.46 \%$ for $\mathrm{K}_{2} \mathrm{O}$ at $48 \mathrm{~kg} /$ Fed and 15.41 and $11.29 \%$ for $\mathrm{K}_{2} \mathrm{O}$ at 24 $\mathrm{kg} / \mathrm{Fed}$, over the control in $1^{\text {st }}$ and $2^{\text {nd }}$ seasons, respectively. The preferable responses on cowpea growth parameters to potassium fertilizer application in the plant growth; are due to the role of potassium in plant metabolism, water transport in xylem, cell elongation and carbohydrate synthesis [16]. Furthermore, potassium fertilizer treatments at different levels showed significant influences on onion growth as plant height, leaf length, leaf number and sheath length [17].

Spraying cowpea plants with Nano mixture of micronutrients at different rates increased plant growth characters compared with control (sprayed with tap water) as showed in Tables 2 and 3. Also, Nano mixture of micronutrients at the rate of $2 \mathrm{~g} / \mathrm{l}$ gave the highest values in cowpea growth parameters, except for plant height in the first season, compared with the other rates under study (Tables 2 and 3). The maximum means of total cowpea dry weight (37.43 and 42.13 g) were recorded in the plants that received Nano mixture of micronutrients at $2 \mathrm{~g} / \mathrm{l}$, while the minimum values (29.19 and $32.85 \mathrm{~g}$ ) was observed in the plants which sprayed with tap water during 2017 and 2018 seasons, respectively. The increases in total dry weight/plant were about 28.22 and $20.24 \%$ Nano mixture of micronutrients at $2 \mathrm{~g} / 1,11.33$ and $20.88 \%$ for Nano mixture of micronutrients at $1 \mathrm{~g} / 1$ and 10.55 and $8.88 \%$ for Nano mixture of micronutrients at $0.5 \mathrm{~g} /$ 1 over the control in $1^{\text {st }}$ and $2^{\text {nd }}$ seasons, respectively. Foliar spraying is a new technique for crop nutrition, which liquid form of micronutrients is applied to leaves [18]. Utilizing microelements in foliar was is more advantageous than using as application soil. Fouda and Abd-Elhamied [19] pointed out that all micronutrients treatments significantly improved vegetative growth (plant height, branch number/plant, leaf number/plant). 
Table 2. Effect of potassium fertilization level, Nano mixture of micronutrients rate and their interaction treatments on plant height, branch and leaf number per plant of cowpea during the two seasons of 2017 and 2018

\begin{tabular}{|c|c|c|c|c|c|c|c|}
\hline \multirow{2}{*}{\multicolumn{2}{|c|}{ Treatments }} & \multicolumn{2}{|c|}{ Plant height $(\mathrm{cm})$} & \multicolumn{2}{|c|}{ Number of branches/plant } & \multicolumn{2}{|c|}{ Number of leaves/plant } \\
\hline & & $1^{\text {st }}$ season & $2^{\text {nd }}$ season & $1^{\text {st }}$ season & $2^{\text {nd }}$ season & $1^{\text {st }}$ season & $2^{\text {nd }}$ season \\
\hline \multicolumn{8}{|c|}{$\mathrm{K}_{2} \mathrm{O}(\mathrm{kg} / \mathrm{Fed})}$. \\
\hline \multicolumn{2}{|c|}{ Control } & 39.41 & 41.05 & 8.97 & 9.47 & 51.55 & 59.08 \\
\hline \multicolumn{2}{|c|}{24} & 40.30 & 42.83 & 10.72 & 11.44 & 64.97 & 72.97 \\
\hline \multicolumn{2}{|c|}{48} & 42.97 & 45.16 & 11.19 & 12.61 & 70.89 & 81.91 \\
\hline \multicolumn{2}{|c|}{72} & 43.47 & 50.41 & 12.22 & 13.11 & 78.58 & 86.75 \\
\hline \multicolumn{2}{|c|}{ LSD at $5 \%$} & 0.58 & 0.39 & 0.47 & 0.39 & 2.04 & 1.36 \\
\hline \multicolumn{8}{|c|}{ Nano-micronutrients mixture rate $(\mathrm{g} / \mathrm{l})$} \\
\hline \multicolumn{2}{|c|}{ Control } & 40.39 & 41.02 & 9.33 & 9.97 & 57.41 & 66.02 \\
\hline \multicolumn{2}{|c|}{0.50} & 41.63 & 44.80 & 10.27 & 11.25 & 63.86 & 72.52 \\
\hline \multicolumn{2}{|c|}{1.00} & 42.72 & 46.13 & 11.55 & 12.16 & 71.30 & 77.27 \\
\hline \multicolumn{2}{|c|}{2.00} & 41.41 & 47.50 & 11.94 & 13.25 & 73.41 & 84.89 \\
\hline \multicolumn{2}{|c|}{ LSD at $5 \%$} & 0.49 & 0.56 & 0.36 & 0.37 & 1.73 & 2.19 \\
\hline \multicolumn{8}{|c|}{ Interaction } \\
\hline \multirow{4}{*}{ Control } & Control & 38.55 & 35.77 & 8.55 & 8.44 & 45.78 & 51.88 \\
\hline & 0.50 & 39.44 & 41.55 & 8.78 & 9.33 & 50.55 & 56.11 \\
\hline & 1.00 & 40.44 & 43.33 & 9.11 & 9.55 & 52.66 & 60.11 \\
\hline & 2.00 & 39.22 & 43.55 & 9.44 & 10.55 & 57.22 & 68.22 \\
\hline \multirow{4}{*}{24} & Control & 39.66 & 38.77 & 9.66 & 10.22 & 58.66 & 68.00 \\
\hline & 0.50 & 40.33 & 42.88 & 9.88 & 10.66 & 60.44 & 69.22 \\
\hline & 1.00 & 40.99 & 44.11 & 11.44 & 11.88 & 69.55 & 74.77 \\
\hline & 2.00 & 40.22 & 45.55 & 11.89 & 12.99 & 71.22 & 79.89 \\
\hline \multirow{4}{*}{48} & Control & 41.77 & 42.55 & 9.55 & 10.66 & 60.89 & 72.66 \\
\hline & 0.50 & 43.66 & 44.44 & 10.66 & 11.77 & 72.88 & 76.33 \\
\hline & 1.00 & 45.22 & 45.88 & 11.99 & 13.77 & 74.77 & 84.11 \\
\hline & 2.00 & 41.22 & 47.77 & 12.55 & 14.22 & 75.00 & 94.55 \\
\hline \multirow{4}{*}{72} & Control & 41.55 & 47.00 & 9.55 & 10.55 & 64.33 & 71.55 \\
\hline & 0.50 & 43.11 & 50.33 & 11.77 & 13.22 & 71.55 & 88.44 \\
\hline & 1.00 & 44.22 & 51.22 & 13.66 & 13.44 & 88.22 & 90.11 \\
\hline & 2.00 & 45.00 & 53.11 & 13.88 & 15.22 & 90.22 & 96.89 \\
\hline \multicolumn{2}{|c|}{ LSD at $5 \%$} & 1.02 & 1.05 & 0.78 & 0.76 & 3.62 & 4.02 \\
\hline
\end{tabular}

The best interaction treatment in cowpea growth parameters was that of potassium fertilization at $72 \mathrm{~kg} \mathrm{~K} / 2 \mathrm{O} / \mathrm{Fed}$. interacted with Nano mixture of micronutrients at $2 \mathrm{~g} / \mathrm{l}$. In general, the interaction between potassium levels and Nano mixture of micronutrients rates significantly increased plant height, branch and leaf numbers and weights per plant and plant branch, leaf and total dry weights compared with the control in both seasons (Tables 2 and 3). Moreover, as abovementioned, both potassium fertilization levels and Nano mixture of micronutrients rates (each alone) increased plant growth of cowpea plant, in turn; they together might maximize their effects leading to taller, more branches and leaves as well as heaviest branches, leaves and total herb. 
Table 3. Effect of potassium fertilization level, Nano mixture of micronutrients rate and their interaction treatments on branch and leaf dry weights per plant as well as total dry weight per plant (g) of cowpea during the two seasons of 2017 and 2018

\begin{tabular}{|c|c|c|c|c|c|c|c|}
\hline \multirow{2}{*}{\multicolumn{2}{|c|}{ Treatments }} & \multicolumn{2}{|c|}{ Dry weight of branches/plant (g) } & \multicolumn{2}{|c|}{ Dry weight of leaves/plant (g) } & \multicolumn{2}{|c|}{ Total dry weight/plant (g) } \\
\hline & & $1^{\text {st }}$ season & $2^{\text {nd }}$ season & $1^{\text {st }}$ season & $2^{\text {nd }}$ season & $1^{\text {st }}$ season & $2^{\text {nd }}$ season \\
\hline \multicolumn{8}{|c|}{$\mathrm{K}_{2} \mathrm{O}$ (kg/Fed.) } \\
\hline \multicolumn{2}{|c|}{ Control } & 11.88 & 14.16 & 16.41 & 18.96 & 28.29 & 33.12 \\
\hline \multicolumn{2}{|c|}{24} & 14.78 & 15.73 & 17.87 & 21.13 & 32.65 & 36.86 \\
\hline \multicolumn{2}{|c|}{48} & 15.86 & 16.13 & 19.30 & 21.46 & 35.16 & 37.58 \\
\hline \multicolumn{2}{|c|}{72} & 17.30 & 18.83 & 20.68 & 24.05 & 37.97 & 42.88 \\
\hline \multicolumn{2}{|c|}{ LSD at $5 \%$} & 0.36 & 0.13 & 0.70 & 0.56 & 0.67 & 0.61 \\
\hline \multicolumn{8}{|c|}{ Nano-micronutrients mixture rate $(\mathrm{g} / \mathrm{l})$} \\
\hline \multicolumn{2}{|c|}{ Control } & 13.19 & 13.52 & 16.00 & 19.33 & 29.19 & 32.85 \\
\hline \multicolumn{2}{|c|}{0.50} & 14.26 & 15.36 & 18.00 & 20.41 & 32.27 & 35.77 \\
\hline \multicolumn{2}{|c|}{1.00} & 15.72 & 17.40 & 19.48 & 22.31 & 35.20 & 39.71 \\
\hline \multicolumn{2}{|c|}{2.00} & 16.66 & 18.57 & 20.77 & 23.56 & 37.43 & 42.13 \\
\hline \multicolumn{2}{|c|}{ LSD at $5 \%$} & 0.25 & 0.44 & 0.33 & 0.43 & 0.39 & 0.55 \\
\hline \multicolumn{8}{|c|}{ Interaction } \\
\hline \multirow{4}{*}{ Control } & Control & 11.18 & 12.28 & 14.83 & 17.12 & 26.01 & 29.40 \\
\hline & 0.50 & 11.60 & 13.80 & 16.42 & 17.81 & 28.02 & 31.61 \\
\hline & 1.00 & 12.17 & 15.11 & 17.08 & 20.10 & 29.25 & 35.21 \\
\hline & 2.00 & 12.59 & 15.46 & 17.30 & 20.81 & 29.89 & 36.27 \\
\hline \multirow{4}{*}{24} & Control & 13.20 & 12.79 & 14.91 & 19.06 & 28.11 & 31.85 \\
\hline & 0.50 & 14.76 & 15.56 & 17.79 & 20.29 & 32.55 & 35.85 \\
\hline & 1.00 & 15.56 & 16.84 & 19.26 & 22.29 & 34.82 & 39.13 \\
\hline & 2.00 & 15.61 & 17.72 & 19.50 & 22.89 & 35.11 & 40.61 \\
\hline \multirow{4}{*}{48} & Control & 13.77 & 13.35 & 16.73 & 19.49 & 30.51 & 32.84 \\
\hline & 0.50 & 14.87 & 14.74 & 18.64 & 20.27 & 33.51 & 35.01 \\
\hline & 1.00 & 16.20 & 17.28 & 20.31 & 22.41 & 36.51 & 39.69 \\
\hline & 2.00 & 18.60 & 19.14 & 21.52 & 23.66 & 40.11 & 42.80 \\
\hline \multirow{5}{*}{\multicolumn{2}{|c|}{$\begin{array}{r}\text { Control } \\
0.50 \\
1.00 \\
2.00\end{array}$}} & 14.60 & 15.65 & 17.52 & 21.65 & 32.12 & 37.30 \\
\hline & & 15.82 & 17.34 & 19.16 & 23.26 & 34.98 & 40.60 \\
\hline & & 18.94 & 20.37 & 21.26 & 24.43 & 40.20 & 44.80 \\
\hline & & 19.83 & 21.96 & 24.76 & 26.85 & 44.59 & 48.82 \\
\hline & & 0.57 & 0.77 & 0.90 & 0.93 & 0.95 & 1.13 \\
\hline
\end{tabular}

The increases in total dry weight/plant were about 71.43 and $66.05 \%$ for the interaction between $\mathrm{K}_{2} \mathrm{O}$ at $72 \mathrm{~kg} / \mathrm{Fed}$; and Nano mixture of micronutrients at $2 \mathrm{~g} / \mathrm{l}, 59.55$ and $52.38 \%$ for the interaction between $\mathrm{K}_{2} \mathrm{O}$ at $72 \mathrm{~kg} / \mathrm{Fed}$; and Nano mixture of micronutrients at $1 \mathrm{~g} / \mathrm{l}, 54.30$ and $45.57 \%$ for the interaction between $\mathrm{K}_{2} \mathrm{O}$ at $48 \mathrm{~kg} / \mathrm{Fed}$; and Nano mixture of micronutrients at $2 \mathrm{~g} / \mathrm{l}$ and 40.36 and $35.00 \%$ for the interaction between $\mathrm{K}_{2} \mathrm{O}$ at $48 \mathrm{~kg} / \mathrm{Fed}$; and Nano mixture of micronutrients at $1 \mathrm{~g} / \mathrm{l}$ over the control in $1^{\text {st }}$ and $2^{\text {nd }}$ seasons, respectively. However, Al-Juthery and Saadoun ${ }^{[20]}$ on artichoke and Abdelkader et al. [10] on fennel plants found similar results.

\subsection{Yield and its components}

It is quite clear from the data in Tables 4 and 5 that, there were significant differences in pod diameter, pod length, 100 seeds weight, number of pods/plant, seed yield/plant and seed yield/Fed. Of cowpea as the response of all the tested potassium fertilization levels. Similarly, these yield components of cowpea were increased gradually by increasing the used potassium fertilization levels. The highest level of potassium ( $72 \mathrm{~kg} \mathrm{~K} / \mathrm{O} / \mathrm{Fed}$ ) recorded significant enhances compared with the other levels and unfertilized plots in both seasons. The increases in seed yield/Fed were about 35.73 and $42.50 \%$ for $\mathrm{K}_{2} \mathrm{O}$ at $72 \mathrm{~kg} / \mathrm{Fed}, 20.94$ and $21.39 \%$ for $\mathrm{K}_{2} \mathrm{O}$ at $48 \mathrm{~kg} / \mathrm{Fed}, 9.98$ and $5.08 \%$ for $\mathrm{K}_{2} \mathrm{O}$ at $24 \mathrm{~kg} / \mathrm{Fed} \mathrm{over}$ the control in $1^{\text {st }}$ and $2^{\text {nd }}$ seasons, respectively. Potassium donates an activation on many physiological processes is thus 
an effect on photosynthesis and carbohydrates translocation from leaves to roots that can have lineal result on cowpea yield. Also, increasing amount of potassium sulphate in the medium participated to an increase in rocket yield [21]. These results agree with those reported by Muoneke et al. [5] and Mansouri and Shokoohfar [6] on cowpea.

There was an increase in pod dimension (cm), 100-seeds weight $(\mathrm{g})$, number of pods/plant, seed yield per plant $(\mathrm{g})$ and seed yield per Fed $(\mathrm{kg})$ of cowpea plants with increasing the tested Nano mixture of micronutrients rate during both seasons (Tables 4 and 5). However, there were significant differences among all rates of Nano mixture of micronutrients especially the rate of $2 \mathrm{~g} / \mathrm{l}$, which gave significant increases compared with untreated plants and the other two rates under study. The prevalence in cowpea pod and seed yield by Nano mixture of micronutrients usage is directly due to the beneficent influence on cowpea growth, which conducted in increases in metabolites syntheses to pods and this in turn increment total seed yield per Fed. Micronutrients are necessary in trace amounts but their sufficed supply promotes nutrient availability and positively influences the cell physiology that is reflected in yield components as well [22-23]. The increase in seed yield/Fed were about 22.03 and $35.25 \%$ for Nano mixture of micronutrients at $2 \mathrm{~g} / \mathrm{l}, 13.26$ and $26.05 \%$ for Nano mixture of micronutrients at $1 \mathrm{~g} / \mathrm{l}$ and 6.99 and $7.87 \%$ for Nano mixture of micronutrients at $0.5 \mathrm{~g} /$ 1 over the control in $1^{\text {st }}$ and $2^{\text {nd }}$ seasons, respectively. The simulative effect of Nano mixture of micronutrients on seed yield of cowpea may be due to that Nano mixture of micronutrients contains six essential substances for plant nutrition ( $\mathrm{Fe}, \mathrm{Zn}, \mathrm{Cu}, \mathrm{Mn}, \mathrm{B}$ and $\mathrm{Mo}$ ).

Table 4. Effect of potassium fertilization level, Nano mixture of micronutrients rate and their interaction treatments on pod diameter (cm), pod length $(\mathrm{cm})$ and 100 seeds weight $(\mathrm{g})$ of cowpea during the two seasons of 2017 and 2018

\begin{tabular}{|c|c|c|c|c|c|c|c|}
\hline \multirow{2}{*}{\multicolumn{2}{|c|}{ Treatments }} & \multicolumn{2}{|c|}{ Pod diameter $(\mathrm{cm})$} & \multicolumn{2}{|c|}{ Pod length (cm) } & \multicolumn{2}{|c|}{100 seeds weight $(\mathrm{g})$} \\
\hline & & $1^{\text {st }}$ season & $2^{\text {nd }}$ season & $1^{\text {st }}$ season & $2^{\text {nd }}$ season & $1^{\text {st }}$ season & $2^{\text {nd }}$ season \\
\hline \multicolumn{8}{|c|}{$\mathrm{K}_{2} \mathrm{O}(\mathrm{kg} / \mathrm{Fed})$} \\
\hline \multicolumn{2}{|c|}{ Control } & 0.56 & 0.58 & 10.94 & 11.30 & 16.80 & 17.21 \\
\hline \multicolumn{2}{|c|}{24} & 0.62 & 0.64 & 11.63 & 12.20 & 17.13 & 17.72 \\
\hline \multicolumn{2}{|c|}{48} & 0.63 & 0.65 & 12.18 & 12.50 & 17.44 & 17.79 \\
\hline \multicolumn{2}{|c|}{72} & 0.65 & 0.67 & 12.44 & 12.95 & 17.70 & 18.25 \\
\hline \multicolumn{2}{|c|}{ LSD at $5 \%$} & 0.01 & 0.01 & 0.20 & 0.39 & 0.39 & 0.29 \\
\hline \multicolumn{8}{|c|}{ Nano-micronutrients mixture rate $(\mathrm{g} / \mathrm{l})$} \\
\hline \multicolumn{2}{|c|}{ Control } & 0.58 & 0.61 & 11.19 & 11.33 & 16.72 & 17.26 \\
\hline \multicolumn{2}{|c|}{0.50} & 0.61 & 0.63 & 11.49 & 11.98 & 16.97 & 17.64 \\
\hline \multicolumn{2}{|c|}{1.00} & 0.63 & 0.64 & 11.93 & 12.64 & 17.53 & 17.87 \\
\hline \multicolumn{2}{|c|}{2.00} & 0.64 & 0.66 & 12.58 & 13.00 & 17.85 & 18.21 \\
\hline \multicolumn{2}{|c|}{ LSD at $5 \%$} & 0.01 & 0.01 & 0.24 & 0.29 & 0.25 & 0.23 \\
\hline \multicolumn{8}{|c|}{ Interaction } \\
\hline \multirow{4}{*}{ Control } & Control & 0.53 & 0.57 & 10.48 & 10.91 & 16.54 & 17.04 \\
\hline & 0.50 & 0.55 & 0.57 & 10.68 & 11.15 & 16.69 & 17.21 \\
\hline & 1.00 & 0.57 & 0.57 & 11.23 & 11.71 & 16.77 & 17.32 \\
\hline & 2.00 & 0.58 & 0.59 & 11.38 & 11.42 & 17.20 & 17.27 \\
\hline \multirow{4}{*}{24} & Control & 0.57 & 0.60 & 10.90 & 11.19 & 16.69 & 16.99 \\
\hline & 0.50 & 0.60 & 0.63 & 11.21 & 12.04 & 16.63 & 17.60 \\
\hline & 1.00 & 0.64 & 0.65 & 11.87 & 12.57 & 17.49 & 17.88 \\
\hline & 2.00 & 0.66 & 0.67 & 12.54 & 13.01 & 17.72 & 18.41 \\
\hline \multirow{4}{*}{48} & Control & 0.60 & 0.62 & 11.34 & 11.58 & 16.79 & 17.35 \\
\hline & 0.50 & 0.64 & 0.65 & 12.06 & 12.18 & 17.28 & 17.73 \\
\hline & 1.00 & 0.64 & 0.66 & 12.24 & 12.97 & 17.77 & 17.83 \\
\hline & 2.00 & 0.66 & 0.68 & 13.08 & 13.28 & 17.93 & 18.25 \\
\hline \multirow{5}{*}{\multicolumn{2}{|c|}{$\begin{array}{l}\text { Control } \\
0.50 \\
1.00 \\
2.00 \\
\text { LSD at } 5 \%\end{array}$}} & 0.63 & 0.65 & 12.03 & 11.64 & 16.87 & 17.66 \\
\hline & & 0.65 & 0.67 & 12.02 & 12.55 & 19.27 & 18.00 \\
\hline & & 0.66 & 0.68 & 12.37 & 13.31 & 18.09 & 18.45 \\
\hline & & 0.68 & 0.70 & 13.34 & 14.29 & 18.55 & 18.90 \\
\hline & & 0.02 & 0.02 & 0.46 & 0.63 & 0.59 & 0.49 \\
\hline
\end{tabular}


Fe is a catalyst to chlorophyll biosynthesis and acts as an oxygen carrier and aids in respiratory enzyme system. $\mathrm{Zn}$ as a cofactor, $\mathrm{Zn}$ is involved in enzyme systems and metabolic reactions and is necessary for the production of chlorophyll and carbohydrates. Mn activates several important metabolic reactions aids in chlorophyll synthesis, in photosynthesis, accelerates germination and maturity and increases the availability of $\mathrm{P}$ and $\mathrm{Ca}$. $\mathrm{Cu}$ is involved in several enzymes systems, cell wall information, electron transport and oxidation reactions. B is related to cell wall strength and development, cell division, fruit and seed development, sugar transport, hormone development, increases flower production and retention, pollen tube elongation as well as germination, seed and fruit development. Mo enables the plant to use the nitrates taken up from the soil. Molybdo enzymes are also involved in the syntheses of the phytohormones ABA and IAA. Also, micronutrients Nano fertilizers may enhance the availability of these micronutrients to plant and increase the crop productivity [9]. These results are inline with those reported by Nadi et al. [24] and Alasvand and Shokufar [25] on cowpea.

Table 5. Effect of potassium fertilization level, Nano mixture of micronutrients rate and their interaction treatments on pod umber/plant, seed yield/plant $(\mathrm{g})$ and seed yield/Fed $(\mathrm{kg})$ of cowpea during the two seasons of 2017 and 2018

\begin{tabular}{|c|c|c|c|c|c|c|c|}
\hline \multirow{2}{*}{\multicolumn{2}{|c|}{ Treatments }} & \multicolumn{2}{|c|}{ Number of pods/plant } & \multicolumn{2}{|c|}{ Seed yield/plant $(g)$} & \multicolumn{2}{|c|}{ Seed yield/Fed (kg) } \\
\hline & & $1^{\text {st }}$ season & $2^{\text {nd }}$ season & $1^{\text {st }}$ season & $2^{\text {nd }}$ season & $1^{\text {st }}$ season & $2^{\text {nd }}$ season \\
\hline \multicolumn{8}{|c|}{$\mathrm{K}_{2} \mathrm{O}(\mathrm{kg} / \mathrm{Fed})$} \\
\hline \multicolumn{2}{|c|}{ Control } & 35.61 & 36.88 & 18.08 & 18.91 & 632.94 & 661.97 \\
\hline \multicolumn{2}{|c|}{24} & 37.75 & 38.44 & 19.89 & 19.87 & 696.12 & 695.62 \\
\hline \multicolumn{2}{|c|}{48} & 39.41 & 46.22 & 21.87 & 22.96 & 765.49 & 803.61 \\
\hline \multicolumn{2}{|c|}{72} & 43.30 & 48.86 & 24.55 & 26.95 & 859.13 & 843.37 \\
\hline \multicolumn{2}{|c|}{ LSD at $5 \%$} & 0.45 & 0.87 & 1.04 & 0.60 & 36.24 & 20.90 \\
\hline \multicolumn{8}{|c|}{ Nano-micronutrients mixture rate $(\mathrm{g} / \mathrm{l})$} \\
\hline \multicolumn{2}{|c|}{ Control } & 36.75 & 39.58 & 19.08 & 18.91 & 667.81 & 661.70 \\
\hline \multicolumn{2}{|c|}{0.50} & 38.39 & 41.75 & 20.41 & 20.39 & 714.50 & 713.78 \\
\hline \multicolumn{2}{|c|}{1.00} & 39.52 & 43.22 & 21.61 & 23.83 & 756.41 & 834.12 \\
\hline \multicolumn{2}{|c|}{2.00} & 41.41 & 45.86 & 23.28 & 25.57 & 814.96 & 894.98 \\
\hline \multicolumn{2}{|c|}{ LSD at $5 \%$} & 0.58 & 0.75 & 0.85 & 0.78 & 29.87 & 27.21 \\
\hline \multicolumn{8}{|c|}{ Interaction } \\
\hline \multirow{4}{*}{ Control } & Control & 34.00 & 35.22 & 16.75 & 17.27 & 586.38 & 604.40 \\
\hline & 0.50 & 35.55 & 36.99 & 18.04 & 18.64 & 631.47 & 652.60 \\
\hline & 1.00 & 35.78 & 36.77 & 18.51 & 19.04 & 647.96 & 666.40 \\
\hline & 2.00 & 37.11 & 38.55 & 19.03 & 20.70 & 665.94 & 724.50 \\
\hline \multirow{4}{*}{24} & Control & 35.77 & 36.55 & 18.45 & 18.57 & 645.68 & 650.20 \\
\hline & 0.50 & 37.22 & 38.00 & 19.69 & 19.35 & 689.13 & 677.30 \\
\hline & 1.00 & 38.22 & 38.89 & 20.06 & 20.47 & 701.95 & 716.30 \\
\hline & 2.00 & 39.77 & 40.33 & 21.36 & 21.10 & 747.72 & 738.70 \\
\hline \multirow{4}{*}{48} & Control & 37.44 & 42.11 & 19.99 & 17.22 & 699.78 & 602.60 \\
\hline & 0.50 & .866 & 45.22 & 20.54 & 18.59 & 718.87 & 650.90 \\
\hline & 1.00 & 39.44 & 47.44 & 22.52 & 26.69 & 788.06 & 934.20 \\
\hline & 2.00 & 42.11 & 50.11 & 24.44 & 29.33 & 855.26 & 1026.70 \\
\hline \multirow{4}{*}{72} & Control & 39.77 & 44.44 & 21.13 & 22.56 & 739.41 & 789.60 \\
\hline & 0.50 & 42.11 & 46.78 & 23.38 & 24.98 & 818.51 & 874.30 \\
\hline & 1.00 & 44.66 & 49.77 & 25.36 & 29.13 & 887.69 & 1019.50 \\
\hline & 2.00 & 46.66 & 54.44 & 28.31 & 31.14 & 990.92 & 1090.00 \\
\hline \multicolumn{2}{|c|}{ LSD at $5 \%$} & 1.11 & 1.55 & 1.80 & 1.47 & 62.97 & 51.47 \\
\hline
\end{tabular}

Under each potassium fertilization level cowpea yield and its components were gradually increased by increasing Nano mixture of micronutrients rates (Tables 4 and 5). Moreover, interaction of the highest level of potassium fertilization ( $72 \mathrm{~kg} \mathrm{~K}$ O/Fed.) with $2 \mathrm{~g} / 1 \mathrm{Nano}$ mixture of micronutrients recorded the highest values in pod diameter, pod length, 100 seeds weight, number of pods/plant, seed yield/plant and seed yield/Fed of cowpea with significant differences compared with untreated plants (without K-fertilization and unsprayed plants with Nano mixture of micronutrients). In addition, under the three tested Nano mixture of micronutrients $(0.5,1.0$ and 2 g/l) different levels of potassium fertilization gave significant increases in abovementioned parameters of cowpea compared with control in 
2017 and 2018 seasons.

Regarding potassium sulphate levels, the maximum level $\left(140 \mathrm{~kg} / \mathrm{ha}{ }^{-1}\right)$ significantly higher in cowpea grain yields for $18.39 \%$ and improve growth compared with unfertilized plants [6]. The highest number of pods per $\mathrm{m}^{2}$, number of pods per plant, number of seeds per pod, seed weight per plant and total seed yield of cowpea belonged to $10 \mathrm{~kg} . \mathrm{ha}^{-1}$ nano zinc chelate treatment and the lowest amount of mentioned characters belonged to control [25]. In addition, the superior results were established when sugar beet plants were applied with Nano-microelements + nitrogen fertilization and classify as the first suitable treatments for root length and diameter and sugar yields in the two seasons [26].

\subsection{Potassium use efficiency (KUE)}

Data in Table 6 shows that KUE by cowpea plants increased by increasing $\mathrm{K}_{2} \mathrm{O}$ up to $72 \mathrm{~kg} / \mathrm{Fed}$. Fertilizing with $\mathrm{K}_{2} \mathrm{O}$ at $72 \mathrm{~kg} /$ Fed. Recorded the highest KUE (3.14 and $3.91 \mathrm{~kg}$ seeds $/ 1 \mathrm{~kg} \mathrm{~K} \mathrm{~K}_{2}$ ) followed by $\mathrm{K}_{2} \mathrm{O}$ at $48 \mathrm{~kg} / \mathrm{Fed}$. (2.76 and $2.95 \mathrm{~kg}$ seeds $/ 1 \mathrm{~kg} \mathrm{~K}_{2} \mathrm{O}$ ) in $1^{\text {st }}$ and $2^{\text {nd }}$ seasons, respectively. Fertilizing cowpea with $\mathrm{K}_{2} \mathrm{O}$ at $72 \mathrm{~kg} / \mathrm{Fed}$; and spraying with Nano mixture of micronutrients at $2 \mathrm{~g} / 1$ recorded maximum KUE by plants $\left(4.51 \mathrm{~kg}\right.$ seeds $\left./ 1 \mathrm{~kg} \mathrm{~K} \mathrm{~K}_{2} \mathrm{O}\right)$ in $1^{\text {st }}$ season, whereas, in $2^{\text {nd }}$ season, fertilizing cowpea with $\mathrm{K}_{2} \mathrm{O}$ at $48 \mathrm{~kg} / \mathrm{Fed}$; and spraying with Nano mixture of micronutrients at $2 \mathrm{~g} / 1$ recorded maximum KUE $\left(6.30 \mathrm{~kg}\right.$ seeds $/ 1 \mathrm{~kg} \mathrm{~K}_{2} \mathrm{O}$ ). In general, KUE by plants increased with $\mathrm{K}_{2} \mathrm{O}$ at 24,48 or 72 $\mathrm{kg} / \mathrm{Fed}$; and Nano mixture of micronutrients at 1 or $2 \mathrm{~g} / \mathrm{l}$ compared with $\mathrm{K}_{2} \mathrm{O}$ at 24,48 or $72 \mathrm{~kg} / \mathrm{Fed}$; and Nano mixture of micronutrients at $0.50 \mathrm{~g} / 1$ and control. This means that spraying cowpea plants with Nano mixture of micronutrients at 1 or $2 \mathrm{~g} / \mathrm{l}$ increased KUE by plants under different levels of $\mathrm{K}_{2} \mathrm{O}(24,48$ or $72 \mathrm{~kg} / \mathrm{Fed})$.

Table 6. Effect of potassium fertilization level, Nano mixture of micronutrients rate and their interaction treatments on potassium use efficiency ( $\mathrm{kg}$ seed yield $/ \mathrm{kg} \mathrm{K}_{2} \mathrm{O}$ ) and total chlorophyll content (SPAD) in leaves of cowpea during the two seasons of 2017 and 2018

\begin{tabular}{|c|c|c|c|c|c|}
\hline \multirow{2}{*}{\multicolumn{2}{|c|}{ Treatments }} & \multicolumn{2}{|c|}{ Potassium use efficiency (KUE) } & \multicolumn{2}{|c|}{ Total chlorophyll content (SPAD) } \\
\hline & & $1^{\text {st }}$ season & $2^{\text {nd }}$ season & $1^{\text {st }}$ season & $2^{\text {nd }}$ season \\
\hline \multicolumn{6}{|c|}{$\mathrm{K}_{2} \mathrm{O}(\mathrm{kg} / \mathrm{Fed})$} \\
\hline \multicolumn{2}{|c|}{ Control } & 0.00 & 0.00 & 42.08 & 43.75 \\
\hline \multicolumn{2}{|c|}{24} & 2.63 & 1.40 & 44.58 & 44.92 \\
\hline \multicolumn{2}{|c|}{48} & 2.76 & 2.95 & 44.50 & 46.00 \\
\hline \multicolumn{2}{|c|}{72} & 3.14 & 3.91 & 45.17 & 46.42 \\
\hline \multicolumn{2}{|c|}{ LSD at $5 \%$} & 1.48 & 0.67 & 0.80 & 0.46 \\
\hline \multicolumn{6}{|c|}{ Nano-micronutrients mixture rate $(\mathrm{g} / \mathrm{l})$} \\
\hline \multicolumn{2}{|c|}{ Control } & 1.74 & 1.11 & 42.83 & 43.83 \\
\hline \multicolumn{2}{|c|}{0.50} & 1.70 & 1.02 & 43.83 & 44.92 \\
\hline \multicolumn{2}{|c|}{1.00} & 2.12 & 3.14 & 44.50 & 45.83 \\
\hline \multicolumn{2}{|c|}{2.00} & 2.97 & 2.99 & 45.17 & 46.50 \\
\hline \multicolumn{2}{|c|}{ LSD at $5 \%$} & 0.89 & 0.65 & 0.53 & 0.46 \\
\hline \multicolumn{6}{|c|}{ Interaction } \\
\hline \multirow{4}{*}{ Control } & Control & 0.00 & 0.00 & 41.67 & 43.33 \\
\hline & 0.50 & 0.00 & 0.00 & 41.67 & 43.33 \\
\hline & 1.00 & 0.00 & 0.00 & 42.33 & 43.67 \\
\hline & 2.00 & 0.00 & 0.00 & 42.67 & 44.67 \\
\hline \multirow{4}{*}{24} & Control & 2.48 & 1.91 & 42.67 & 42.67 \\
\hline & 0.50 & 2.40 & 1.03 & 44.67 & 44.33 \\
\hline & 1.00 & 2.25 & 2.08 & 45.33 & 45.67 \\
\hline & 2.00 & 3.41 & 0.59 & 45.67 & 47.00 \\
\hline \multirow{4}{*}{48} & Control & 2.36 & 0.04 & 42.33 & 44.33 \\
\hline & 0.50 & 2.82 & 0.04 & 43.67 & 45.33 \\
\hline & 1.00 & 2.92 & 5.58 & 45.67 & 47.67 \\
\hline & 2.00 & 3.95 & 6.30 & 46.33 & 46.67 \\
\hline \multirow{4}{*}{72} & Control & 2.13 & 2.57 & 44.67 & 45.00 \\
\hline & 0.50 & 2.60 & 3.08 & 45.33 & 46.67 \\
\hline & 1.00 & 3.33 & 4.91 & 44.67 & 46.33 \\
\hline & 2.00 & 4.51 & 5.07 & 46.00 & 47.67 \\
\hline \multicolumn{2}{|c|}{ LSD at $5 \%$} & 2.13 & 1.31 & 1.21 & 0.91 \\
\hline
\end{tabular}




\subsection{Chemical constituents in leaves and seed quality}

Total chlorophyll content, nitrogen (\%),phosphorus (\%) and potassium (\%)in cowpea leaves as well as total carbohydrates, $\mathrm{N}$, protein, $\mathrm{P}$ and $\mathrm{K}$ percentages in cowpea seeds were gradually increased by increasing potassium fertilization level (Tables 6, 7, 8 and 9). Likewise, three potassium fertilization levels under study gave significant responses in this regard compared to control in 2017 and 2018 seasons. Also, the highest values in cowpea chemical constituents were achieved by the potassium level of $(72 \mathrm{~kg} \mathrm{~K} 2 \mathrm{O} / \mathrm{Fed})$ compared to control in the two seasons.

In the same time, Nurzynska-Wierdak et al. [21] found that potassium fertilization increased the contents of $\mathrm{N}$, $\mathrm{P}$ and $\mathrm{K}$ in garden rocket plants. Also, Behairy et al. [27] reported that total carbohydrates content in leaves as well as onion bulb chemical composition (N, P, K and protein) were increased with increasing potassium fertilization rate. Furthermore, Zyada and Bardisi [28] pointed out that potassium sulphate at 120 or $150 \mathrm{~kg} / \mathrm{Fed}$ was the best levels used for its superiority in producing the higher TSS and NPK percentages in bulb and leaves of garlic compared to the lowest levels under study.

Table 7. Effect of potassium fertilization level, Nano mixture of micronutrients rate and their interaction treatments on nitrogen (\%), phosphorus (\%) and potassium (\%) in leaves of cowpea during the two seasons of 2017 and 2018

\begin{tabular}{|c|c|c|c|c|c|c|c|}
\hline \multirow{2}{*}{\multicolumn{2}{|c|}{ Treatments }} & \multicolumn{2}{|c|}{ nitrogen $(\%)$} & \multicolumn{2}{|c|}{ phosphorus (\%) } & \multicolumn{2}{|c|}{ potassium $(\%)$} \\
\hline & & $1^{\text {st }}$ season & $2^{\text {nd }}$ season & $1^{\text {st }}$ season & $2^{\text {nd }}$ season & $1^{\text {st }}$ season & $2^{\text {nd }}$ season \\
\hline \multicolumn{8}{|c|}{$\mathrm{K}_{2} \mathrm{O}(\mathrm{kg} / \mathrm{Fed})$} \\
\hline \multicolumn{2}{|c|}{ Control } & 2.298 & 2.367 & 0.355 & 0.362 & 1.476 & 1.463 \\
\hline \multicolumn{2}{|c|}{24} & 2.348 & 2.386 & 0.382 & 0.400 & 1.507 & 1.526 \\
\hline \multicolumn{2}{|c|}{48} & 2.363 & 2.404 & 0.458 & 0.433 & 1.628 & 1.572 \\
\hline \multicolumn{2}{|c|}{72} & 2.375 & 2.422 & 0.457 & 0.465 & 1.613 & 1.633 \\
\hline \multicolumn{2}{|c|}{ LSD at $5 \%$} & 0.008 & 0.010 & 0.010 & 0.008 & 0.012 & 0.12 \\
\hline \multicolumn{8}{|c|}{ Nano-micronutrients mixture rate $(\mathrm{g} / \mathrm{l})$} \\
\hline \multicolumn{2}{|c|}{ Control } & 2.291 & 2.363 & 0.378 & 0.376 & 1.489 & 1.450 \\
\hline \multicolumn{2}{|c|}{0.50} & 2.343 & 2.387 & 0.403 & 0.408 & 1.533 & 1.538 \\
\hline \multicolumn{2}{|c|}{1.00} & 2.361 & 2.403 & 0.426 & 0.433 & 1.582 & 1.583 \\
\hline \multicolumn{2}{|c|}{2.00} & 2.389 & 2.425 & 0.444 & 0.442 & 1.621 & 1.624 \\
\hline \multicolumn{2}{|c|}{ LSD at $5 \%$} & 0.010 & 0.008 & 0.007 & 0.004 & 0.009 & 0.008 \\
\hline \multicolumn{8}{|c|}{ Interaction } \\
\hline \multirow{4}{*}{ Control } & Control & 2.240 & 2.343 & 0.333 & 0.347 & 1.447 & 1.383 \\
\hline & 0.50 & 2.287 & 2.367 & 0.357 & 0.360 & 1.463 & 1.447 \\
\hline & 1.00 & 2.310 & 2.373 & 0.363 & 0.367 & 1.487 & 1.487 \\
\hline & 2.00 & 2.357 & 2.383 & 0.367 & 0.373 & 1.507 & 1.537 \\
\hline \multirow{4}{*}{24} & Control & 2.297 & 2.367 & 0.367 & 0.377 & 1.460 & 1.427 \\
\hline & 0.50 & 2.353 & 2.383 & 0.367 & 0.387 & 1.473 & 1.520 \\
\hline & 1.00 & 2.357 & 2.397 & 0.387 & 0.413 & 1.523 & 1.563 \\
\hline & 2.00 & 2.387 & 2.397 & 0.407 & 0.423 & 1.570 & 1.593 \\
\hline \multirow{4}{*}{48} & Control & 2.307 & 2.377 & 0.400 & 0.383 & 1.513 & 1.470 \\
\hline & 0.50 & 2.363 & 2.387 & 0.433 & 0.423 & 1.607 & 1.563 \\
\hline & 1.00 & 2.383 & 2.403 & 0.483 & 0.450 & 1.683 & 1.593 \\
\hline & 2.00 & 2.397 & 2.450 & 0.513 & 0.473 & 1.710 & 1.663 \\
\hline \multirow{4}{*}{72} & Control & 2.320 & 2.367 & 0.410 & 0.397 & 1.537 & 1.520 \\
\hline & 0.50 & 2.370 & 2.413 & 0.457 & 0.463 & 1.587 & 1.620 \\
\hline & 1.00 & 2.393 & 2.440 & 0.470 & 0.503 & 1.633 & 1.690 \\
\hline & 2.00 & 2.417 & 2.470 & 0.490 & 0.497 & 1.700 & 1.703 \\
\hline \multicolumn{2}{|c|}{ LSD at $5 \%$} & 0.019 & 0.017 & 0.016 & 0.011 & 0.019 & 0.018 \\
\hline
\end{tabular}


Table 8. Effect of potassium fertilization level, Nano mixture of micronutrients rate and their interaction treatments on nitrogen (\%), phosphorus (\%) and potassium (\%) in dry seeds of cowpea during the two seasons of 2017 and 2018

\begin{tabular}{|c|c|c|c|c|c|c|c|}
\hline \multirow{2}{*}{\multicolumn{2}{|c|}{ Treatments }} & \multicolumn{2}{|c|}{ nitrogen $(\%)$} & \multicolumn{2}{|c|}{ phosphorus (\%) } & \multicolumn{2}{|c|}{ potassium $(\%)$} \\
\hline & & $1^{\text {st }}$ season & $2^{\text {nd }}$ season & $1^{\text {st }}$ season & $2^{\text {nd }}$ season & $1^{\text {st }}$ season & $2^{\text {nd }}$ season \\
\hline \multicolumn{8}{|c|}{$\mathrm{K}_{2} \mathrm{O}(\mathrm{kg} / \mathrm{Fed})$} \\
\hline \multicolumn{2}{|c|}{ Control } & 3.367 & 3.201 & 0.520 & 0.528 & 2.608 & 2.698 \\
\hline \multicolumn{2}{|c|}{24} & 3.409 & 3.365 & 0.553 & 0.583 & 2.650 & 2.837 \\
\hline \multicolumn{2}{|c|}{48} & 3.581 & 3.634 & 0.555 & 0.591 & 2.841 & 2.966 \\
\hline \multicolumn{2}{|c|}{72} & 3.609 & 3.649 & 0.594 & 0.621 & 2.930 & 3.059 \\
\hline \multicolumn{2}{|c|}{ LSD at $5 \%$} & 0.011 & 0.006 & 0.025 & 0.015 & 0.044 & 0.020 \\
\hline \multicolumn{8}{|c|}{ Nano-micronutrients mixture rate $(\mathrm{g} / \mathrm{l})$} \\
\hline \multicolumn{2}{|c|}{ Control } & 3.457 & 3.404 & 0.510 & 0.518 & 2.626 & 2.751 \\
\hline \multicolumn{2}{|c|}{0.50} & 3.477 & 3.433 & 0.529 & 0.563 & 2.708 & 2.853 \\
\hline \multicolumn{2}{|c|}{1.00} & 3.498 & 3.482 & 0.578 & 0.608 & 2.777 & 2.928 \\
\hline \multicolumn{2}{|c|}{2.00} & 3.532 & 3.530 & 0.604 & 0.634 & 2.919 & 3.029 \\
\hline \multicolumn{2}{|c|}{ LSD at $5 \%$} & 0.008 & 0.012 & 0.011 & 0.009 & 0.033 & 0.015 \\
\hline \multicolumn{8}{|c|}{ Interaction } \\
\hline \multirow{4}{*}{ Control } & Control & 3.337 & 3.087 & 0.497 & 0.460 & 2.453 & 2.610 \\
\hline & 0.50 & 3.353 & 3.153 & 0.507 & 0.500 & 2.623 & 2.660 \\
\hline & 1.00 & 3.367 & 3.267 & 0.530 & 0.567 & 2.633 & 2.697 \\
\hline & 2.00 & 3.400 & 3.297 & 0.547 & 0.583 & 2.723 & 2.827 \\
\hline \multirow{4}{*}{24} & Control & 3.390 & 3.330 & 0.507 & 0.530 & 2.603 & 2.713 \\
\hline & 0.50 & 3.393 & 3.337 & 0.520 & 0.563 & 2.627 & 2.837 \\
\hline & 1.00 & 3.407 & 3.373 & 0.580 & 0.607 & 2.650 & 2.883 \\
\hline & 2.00 & 3.447 & 3.420 & 0.603 & 0.633 & 2.720 & 2.913 \\
\hline \multirow{4}{*}{48} & Control & 3.533 & 3.600 & 0.497 & 0.513 & 2.663 & 2.783 \\
\hline & 0.50 & 3.567 & 3.613 & 0.507 & 0.583 & 2.760 & 2.893 \\
\hline & 1.00 & 3.597 & 3.630 & 0.587 & 0.620 & 2.843 & 3.030 \\
\hline & 2.00 & 3.627 & 3.693 & 0.630 & 0.647 & 3.097 & 3.157 \\
\hline \multirow{4}{*}{72} & Control & 3.567 & 3.600 & 0.540 & 0.570 & 2.783 & 2.897 \\
\hline & 0.50 & 3.593 & 3.627 & 0.583 & 0.603 & 2.820 & 3.020 \\
\hline & 1.00 & 3.623 & 3.660 & 0.617 & 0.637 & 2.980 & 3.100 \\
\hline & 2.00 & 3.653 & 3.710 & 0.637 & 0.673 & 3.137 & 3.220 \\
\hline \multicolumn{2}{|c|}{ LSD at $5 \%$} & 0.018 & 0.021 & 0.031 & 0.022 & 0.071 & 0.034 \\
\hline
\end{tabular}

All Nano mixture of micronutrients rate treatments gave high significant differences in N, P and $\mathrm{K}$ percentages in cowpea leaves and seeds as well as percentages of total carbohydrates and protein in cowpea seeds, beside, total chlorophyll content in cowpea leaves compared to control, in most cases (Tables 6, 7, 8 and 9). Moreover, increasing rates of Nano mixture of micronutrients gradually increased cowpea chemical constituents. Generally, the highest rate of Nano mixture of micronutrients $(2 \mathrm{~g} / \mathrm{l})$ recorded the highest values in this concern. In addition, there was significant difference between the treatments of $0.50,1.0$ or $2.0 \mathrm{~g} / 1$ Nano mixture of micronutrients in both seasons. These results are in harmony with those stated by Dewdar et al. [26] on sugar beet and Kopittke et al. [29] on several plants. 
Table 9. Effect of potassium fertilization level, Nano mixture of micronutrients rate and their interaction treatments on protein (\%) and total carbohydrates $(\%)$ in seeds of cowpea during the two seasons of 2017 and 2018

\begin{tabular}{|c|c|c|c|c|c|}
\hline & \multirow{2}{*}{ Treatments } & \multicolumn{2}{|c|}{ protein $(\%)$ in seed } & \multicolumn{2}{|c|}{ Total carbohydrates (\%) in seed } \\
\hline & & $1^{\text {st }}$ season & $2^{\text {nd }}$ season & $1^{\text {st }}$ season & $2^{\text {nd }}$ season \\
\hline \multicolumn{6}{|c|}{$\mathrm{K}_{2} \mathrm{O}(\mathrm{kg} / \mathrm{Fed})$} \\
\hline \multicolumn{2}{|r|}{ Control } & 21.03 & 20.01 & 44.88 & 46.34 \\
\hline \multicolumn{2}{|r|}{24} & 21.31 & 21.03 & 49.00 & 48.33 \\
\hline \multicolumn{2}{|r|}{48} & 22.38 & 22.72 & 51.32 & 51.19 \\
\hline \multicolumn{2}{|r|}{72} & 22.56 & 22.81 & 52.66 & 52.17 \\
\hline \multicolumn{2}{|r|}{ LSD at $5 \%$} & 0.07 & 0.04 & 0.53 & 0.31 \\
\hline \multicolumn{6}{|c|}{ Nano-micronutrients mixture rate $(\mathrm{g} / \mathrm{l})$} \\
\hline \multicolumn{2}{|r|}{ Control } & 21.61 & 21.28 & 47.57 & 48.06 \\
\hline \multicolumn{2}{|r|}{0.50} & 21.73 & 21.46 & 48.80 & 49.57 \\
\hline \multicolumn{2}{|r|}{1.00} & 21.87 & 21.77 & 50.31 & 49.68 \\
\hline \multicolumn{2}{|r|}{2.00} & 22.07 & 22.06 & 51.19 & 50.71 \\
\hline \multicolumn{2}{|r|}{ LSD at $5 \%$} & 0.05 & 0.08 & 0.31 & 0.25 \\
\hline \multicolumn{6}{|c|}{ Interaction } \\
\hline \multirow{4}{*}{ Control } & Control & 20.86 & 19.29 & 43.85 & 45.94 \\
\hline & 0.50 & 20.96 & 19.71 & 44.26 & 46.24 \\
\hline & 1.00 & 21.04 & 20.42 & 45.16 & 46.36 \\
\hline & 2.00 & 21.25 & 20.60 & 46.25 & 46.81 \\
\hline \multirow{3}{*}{24} & Control & 21.19 & 20.81 & 46.90 & 46.20 \\
\hline & 0.50 & 21.21 & 20.86 & 48.68 & 49.14 \\
\hline & 1.00 & 21.29 & 21.09 & 50.32 & 48.26 \\
\hline \multirow{4}{*}{48} & 2.00 & 21.54 & 21.38 & 50.11 & 49.70 \\
\hline & Control & 22.08 & 22.50 & 49.39 & 50.09 \\
\hline & 0.50 & 22.29 & 22.58 & 50.24 & 50.56 \\
\hline & 1.00 & 22.48 & 22.69 & 52.18 & 51.44 \\
\hline \multirow{5}{*}{72} & 2.00 & 22.67 & 23.09 & 53.47 & 52.66 \\
\hline & Control & 22.29 & 22.50 & 50.13 & 50.01 \\
\hline & 0.50 & 22.46 & 22.67 & 52.02 & 52.33 \\
\hline & 1.00 & 22.65 & 22.88 & 53.58 & 52.67 \\
\hline & 2.00 & 22.84 & 23.19 & 54.91 & 53.68 \\
\hline \multicolumn{2}{|r|}{ LSD at $5 \%$} & 0.11 & 0.14 & 0.75 & 0.54 \\
\hline
\end{tabular}

Generally, the interaction treatments between potassium fertilization level and Nano mixture of micronutrients rate increased $\mathrm{N}, \mathrm{P}$ and $\mathrm{K}$ percentages in each leaves and seeds of cowpea as well as total protein percentage and total carbohydrates percentages in seeds and total chlorophyll (SPAD) in cowpea leaf tissues as compared the control. In addition, the highest values in this regard were obtained from interaction treatment between potassium fertilization level of $\left(72 \mathrm{~kg} \mathrm{~K}{ }_{2} \mathrm{O} / \mathrm{Fed}\right)$ and Nano mixture of micronutrients at $2 \mathrm{~g} / \mathrm{l}$ in both seasons, with a significant increase compared to untreated cowpea plots. Likewise, increased the interacted Nano mixture of micronutrients rate from $0.5,1.0$ to $2.0 \mathrm{~g} / \mathrm{l}$ resulted in significant increases in cowpea chemical constituents under different levels of potassium fertilization. Also, Temiz et al. [30] reported that application of potassium and micronutrients increased $\mathrm{K}^{+}$rates in cotton leaf compared with the untreated control. In the same trend, Fouda and Abd-Elhamied [19] demonstrated that the interaction effect between chemical fertilization and micronutrients show a enhancing effect on chlorophyll content, quality parameters and available $\mathrm{N}, \mathrm{P}$ and $\mathrm{K}$ in cowpea seeds. 


\section{Conclusion}

The above results stated that the cowpea plant growth, yield components as well as chemical constituents were responded to potassium fertilization soil application and Nano mixture of micronutrients foliar spray. Generally, application of $72 \mathrm{~kg} \mathrm{~K} 2 \mathrm{O} / \mathrm{Fed}$ combined with $2 \mathrm{~g} / \mathrm{l}$ of Nano mixture gave the highest results of growth and productivity of cowpea (Vignaunguiculata L. Walp.) plants grown in clay soil under Sharkia Governorate conditions.

\section{Reference}

[1] Muoneke, CO, OO Ndukwe, PI Okocha, AU Akpan. Growth and yield responses of vegetable cowpea (Vignaunguiculata (L.) Walp) to varying rates of phosphorus and potassium fertilizers. Journal of Applied Agricultural Research. 2015; 7: 123-131.

[2] Ahmed ME, A. A. Elzaawely. Growth and yield of cowpea plants in response to organic fertilization. Australian Journal of Basic and Applied Sciences. 2010; 4(8): 3244-3249.

[3] Abd El-Mageed, Y. T., S. A. El-Shobaky, O. F. Dakhly. Effect of inoculation with Rhizobium mutants and foliar spray with ortho-phosphoric acid on growth and yield of cowpea. 5th ed. Ismailia, Egypt; 2001. p.75-85.

[4] Page, MJ, E Di Cera. Role of $\mathrm{Na}^{+}$and $\mathrm{K}^{+}$in enzyme function. Physiol. Rev. 2006; 86: 1049-1092.

[5] Wiedenhoeft, A C. Plant Nutrition. Hopkins WG the green world. New York NY, Chelsea House publisher; 2006. p.16-43.

[6] Mansouri, S., A Shokoohfar. Effect of potassium fertilizer and irrigation intervals levels on yield and yield components of cowpea (vignaunguiculata) in Ahvaz condition. Indian Journal of Fundamental and Applied Life Sciences. 2015; 5(1): 26-31.

[7] Froggett, S. Nanotechnology and agricultural trade. OECD Conference on the Potential Environmental Benefits of Nanotechnology: Fostering Safe Innovation-Led Growth. 2009.

[8] DeRosa, M. C., C. Monreal, M. Schnitzer, R. Walsh, Y. Sultan. Nanotechnology in fertilizers. Nature Nanotechnology. 2010; 5: 91.

[9] Dey, JK, S. Das, L. G. Mawlong. Nanotechnology and its importance in micronutrient fertilization. Int. J. Curr. Microbiol. App. Sci. 2018; 7(5): 2306-2325.

[10] Abdelkader, MAI, Ibrahim F. R., EE Metwaly. Growth and productivity of fennel (Foeniculumvulgare, Mill) plants as affected by phosphorus rate and nano-micronutrients concentration. J. Plant Production, Mansoura Univ. 2019; 10(7): 483-488.

[11] Chapman, DH, RF Pratt. Methods of A nalysis for Soils, Plants and Waters. Div. Agric. Sci. USA, University of California; 1978. p.16-38.

[12] Markwell, J, JC Osterman, JL Mitchell. Calibration of the Minolta SPAD-502 leaf chlorophyll meter. Photosynthesis Research. 1995; 46: 467-472.

[13] Janssen, BH. Efficient use of nutrients: An art on balancing. Field Crops Res. 1998; 56: 197-201.

[14] Gomez, NK, AA Gomez. Statical Procedures for Agricultural Research. 2nd ed. New York, USA: John wiley and sons; 1984. p.680.

[15] Analytical Software. Statistix Version 9, Analytical Software. Tallahassee, Florida, USA; 2008.

[16] Mengel, K., EA Kirkby. Principles of Plant Nutrition. Dordrecht: Kluwer Academic Publishers; 2001. p.849.

[17] Bekele, M. Effects of different levels of potassium fertilization on yield, quality and storage life of onion (Allium cepa L.) at Jimma, Southwestern Ethiopia. J. Food Sci. Nutr. 2018; 2(1): 32-39.

[18] Nasiri, Y, S Zehtab-Salmasi, S Nasrullahzadeh, N Najafi, K Ghassemi-Golezani. Effects of foliar application of micronutrients ( $\mathrm{Fe}$ and $\mathrm{Zn}$ ) on flower yield and essential oil of chamomile (Matricariachamomilla L.). J. Med. Plants Res. 2010; 4(17): 1733-1737.

[19] Fouda, K F, AS Abd-Elhamied. Integrated effect of foliar fertilization of Fe, $\mathrm{Zn}$ and rates of P fertilization on growth and yield of cowpea. J. Soil Sci. and Agric. Eng. 2017; 8(12): 733-740.

[20] Al-Juthery, HWA, SF Saadoun. Impact of foliar application of some micronutrients nano-fertilizer on growth and yield of Jerusalem artichoke. Iraqi Journal of Agricultural Sciences. 2018; 49(4): 755-787.

[21] Nurzynska-Wierdak, R, Dzida, K, Rozek E, Z Jarosz. Effects of nitrogen and potassium fertilization on growth, yield and chemical composition of garden rocket. Acta Sci. Pol. 2012; 11(2): 289-300.

[22] Taiwo, LB, JA Adediran, MO Akande, VA Banjoko, GA Oluwatosin. Influence of legume fallow on soil properties and yield of maize in South Western. Nigerian J. Agric. Trop. \& Subtrop. 2001; 102: 109-117. 
[23] Boghdady, MS. Role of micronutrients in improving yield and quality of seeds in fenugreek plants (Trigonellafoenim-graecum, L.). Egypt. J. Agron. 2017; 39(3): 267-277.

[24] Nadi, E, A Aynehband, M Mojaddam. Effect of nano-iron chelate fertilizer on grain yield, protein percent and chlorophyll content of Faba bean (Vicia faba L.). International Journal of Biosciences. 2013; 3(9): 267-272.

[25] Alasvand, P, A Shokohfar. Evaluation effect of different levels of zinc and manganese nano-chelate on quantitative and qualitative traits of cowpea (Vignaunguiculata L.). J. Crop. Nut. Sci. 2015; 3(3): 1-13.

[26] Dewdar, MDH, MS Abbas, AS El-Hassanin, HA Abd El-Aleem. Micronutrients and nitrogen foliar applications on sugar beet (Beta vulgaris L.) of quantity and quality traits in marginal soils in Egypt. Int. J. Curr. Microbiol. App. Sci. 2018; 7(8): 4490-4498.

[27] Behairy, AG, AR Mahmoud, MR Shafeek, AH Ali, MM Hafez. Growth, yield and bulb quality of onion plants (Allium cepa L.) as affected by foliar and soil application of potassium. Middle East Journal of Agriculture Research. 2015; 4(1): 60-66.

[28] Zyada, H G, Bardisi E A. Effect of potassium application methods on garlic plants grown under sandy soil conditions. Zagazig J. Agric. Res. 2018; 45(6): 1941-1951.

[29] Kopittke, PM, EnzoLombi, B Peng Wang, Jan K Schjoerringd, Søren Husted. Nanomaterials as fertilizers for improving plant mineral nutrition and environmental outcomes. Environ. Sci. Nano. 2019; 6: 3513-3524.

[30] Temiz M, YK Koca, F Aydin, E Karahan. Effect of foliar potassium and micronutrient additions on yield and fiber quality of cotton (Gossypiumhirsutum L.). Journal of Food, Agriculture \& Environment. 2009; 7(1): 118-122. 